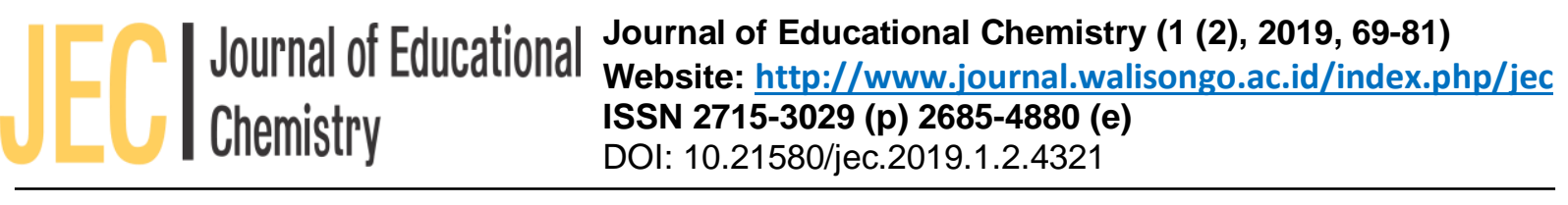

\title{
Pengembangan Modul Bermuatan Pendidikan Karakter Materi Elektrokimia Program Keahlian Teknik Instalasi Tenaga Listrik
}

\author{
Nur Aeni \\ Pendidikan Kimia, Universitas Islam Negeri Walisongo Semarang \\ E-mail : nuraenid27@gmail.com
}

\begin{abstract}
This research is based on the finding of a moral degradation toward the students as same as fighting and cheating, the lack of high school chemistry and available learning resources has not been integrated into the learners' skills program. The aim of this study is to produce an electrochemical learning module with an education-charged character skills program electrical instalation (TITL). This development research uses the Research and Development method with the 4D model of Thiagarajan. The subject of this research is partisipants in the Characteristics of the Module Quality Test Result by subject matter and media experts at stage 1 indicate that the module is reasonably viable by 0.76 rerate score. At the phase 2 is showed an increase in 0.8 with a category of fit. Learners' response percentage is $85.3 \%$ with a very valid category. Based on the validation and the learners' responses, data can be found that a chemical modul contains with a rich educational character program installation engineering expertise is worthy and can be used as a learning resource for learners.
\end{abstract}

Keywords: module, vocational secondary school (SMK), educational character, technique of program electrical installation, electrochemical 


\begin{abstract}
Abstrak
Penelitian ini didasarkan pada masih ditemukannya kasus degradasi moral di kalangan peserta didik seperti kasus tawuran dan kebiasaan mencontek, kurangnya sumber belajar kimia SMK serta sumber belajar yang tersedia belum terintegrasi dengan program keahlian peserta didik. Tujuan penelitian ini yaitu untuk menghasilkan modul pembelajaran elektokimia bermuatan pendidikan karakter program keahlian Teknik Instalasi Tenaga Listrik (TITL). Penelitian pengembangan ini menggunakan metode Research and Development dengan model 4D dari Thiagarajan. Subjek dari penelitian ini adalah peserta didik kelas X program keahlian TITL SMK N 5 Semarang. Karakteristik modul Hasil uji kualitas modul menurut ahli materi dan media pada tahap 1 menunjukkan bahwa modul cukup layak dengan skor rerata 0,76. Pada tahap 2 mengalami peningkatan sebesar 0,8 dengan kategori sangat layak. Persentase respon/tanggapan peserta didik sebesar 85,3\% dengan kategori sangat valid. Berdasarkan data hasil uji validasi dan tanggapan peserta didik maka dapat disimpulkan bahwa modul kimia bermuatan pendidikan karakter program keahlian Teknik Instalasi Tenaga Listrik layak dan dapat digunakan sebagai sumber belajar peserta didik.
\end{abstract}

Kata Kunci: modul, SMK, pendidikan karakter, teknik instalasi tenaga listrik, elektrokimia

\title{
Pendahuluan
}

Sekolah Menengah Kejuruan (SMK) merupakan lembaga pendidikan yang lulusannya diharapkan mampu berkompetensi di dunia kerja. Oleh sebab itu selain memiliki hard skill lulusannya dituntut memiliki soft skill yang menunjang di dunia kerja. Hard skill dapat terbentuk melalui masing-masing bidang keahlian peserta didik. Sedangkan soft skill merupakan keterampilan kepribadian yang terbentuk karena penanaman nilai kebajikan (Zamtinah, et.al., 2011).

Pengembangan pendidikan tidak bertujuan mengembangkan aspek pemikiraan saja, tetapi juga mengembangkan watak, moral, sosial dan fisik peserta didik. Pendidikan untuk membentuk manusia seutuhnya. Upaya ini dilakukan dalam rangka meningkatkan sumber daya manusia Indonesia dan mutu pendidikan. 70

Copyright (C) 2019 JEC | ISSN 2715-3029 (p) 2685-4880 (e)

Volume 1, Nomor 2, 2019
Sejak 2500 tahun yang lalu, Socrates merumuskan tujuan dasar dari pendidikan adalah membuat orang menjadi good and smart. Rasulullah Saw dalam sejarah Islam juga menegaskan bahwa misi utamanya adalah mendidik manusia dan menyepurnakan akhlak serta mengupayakan pembentukkan karakter yang baik (good character) (Majid dan Andayani, 2011).

Pengembangan pendidikan karakter pada kurikulum 2013 harus didukung semua kalangan. Pendidikan karakter bukan hanya penting, tetapi mutlak dilakukan oleh setiap bangsa jika ingin menjadi bangsa yang beradab. Banyak bukti yang menguatkan bahwa bangsabangsa yang maju tidak dipengaruhi oleh sumber daya alam yang melimpah yang dimiliki, tetapi karena sumber daya manusianya 
memiliki karakter yang unggul. Karakter unggul tersebut dapat ditanamkan melalui pendidikan karakter (Haryati, 2013).

Pendidikan karakter menjadi sesuatu yang penting untuk membentuk generasi yang berkualitas. Pendidikan karakter dapat dijadikan sebagai wadah atau proses untuk membentuk pribadi anak agar menjadi pribadi yang baik. Pada dunia pendidikan, pendidikan karakter sangat dibutuhkan oleh peserta didik untuk membentuk pribadi yang baik, bijaksana, jujur, bertanggungjawab dan bisa menghormati orang lain. Karakter-karakter tersebut sangat penting untuk bekal peserta didik ketika terjun ke dunia kerja. Hasil penelitian Fitri (seperti dikutip dalam Haryati, 2013) menunjukkan bahwa pendidikan karakter dapat diintegrasikan dalam pembelajaran. Materi pelajaran yang berkaitan dengan norma atau nilai-nilai pada setiap mata pelajaran perlu dikembangkan, dieksplisitkan, dikaitkan dengan konteks kehidupan sehari-hari. Karena itu, pembelajaran nilai-nilai karakter seharusnya tidak diberikan pada arah kognitif saja, tetapi menyentuh internalisasi dan pengalaman nyata dalam kehidupan nyata peserta didik sehari-hari di sekolah dan di masyarakat. Pentingnya pendidikan karakter tersebut mengharuskan semua sekolah menerapkan pendidikan karakter dalam kegiatan belajar mengajarnya.

SMK Negeri 5 Semarang merupakan salah satu sekolah menengah kejuruan yang berada di kota Semarang. Berdasarkan hasil prariset yang dilakukan di SMK Negeri 5 Semarang diketahui bahwa dalam kegiatan belajar mengajar sekolah sudah menerapkan pendidikan karakter untuk peserta didik, di antaranya gerakan bersalaman dengan guru piket sebelum masuk ke sekolah, shalat Duha bagi peserta didik yang beragama Islam dan menyanyikan lagu Indonesia Raya setiap pagi sebelum kegiatan belajar mengajar dilakukan. Akan tetapi masih ditemukan peserta didik yang memiliki kesopanan rendah, seperti berbicara kotor terhadap teman ataupun gurunya. Hasil angket menunjukkan bahwa sebanyak $57 \%$ peserta didik masih melihat teman-teman di sekolah mereka tawuran dengan sekolah lain, $62 \%$ peserta didik tidak antusias dalam belajar kelompok dan lebih senang menonton TV serta $45 \%$ peserta didik mengaku bekerja sama / mencontek saat ujian berlangsung. Selain itu diketahui bahwa hasil belajar peserta didik masih rendah, salah satunya pada materi elektrokimia. Berdasarkan hasil angket peserta didik rendahnya hasil belajar tersebut disebabkan karena kurangnya minat peserta didik terhadap pelajaran kimia, sebanyak $84 \%$ tidak menyukai pelajaran kimia. Sedangkan sebanyak $78 \%$ peserta didik mengaaku tidak memiliki buku yang dapat dijadikan pegangan peserta didik dalam pembelajaran kimia.

Rendahnya hasil belajar serta moral peserta didik menyebabkan perlu dilakukannya sebuah perbaikan untuk mengatasi permasalahan tersebut, salah satunya melalui mata pelajaran kimia. Perbaikan tersebut dapat melalui pembelajaran kimia yang materimaterinya dikaitkan dengan kehidupan seharihari peserta didik. Selain itu pelajaran kimia tersebut dihubungkan dengan program keahlian peserta didik dan disertai penyisipan karakter di dalamnya. Penyisipan karakter tersebut dapat melalui bahan ajar pembelajaran kimia. Nilai karakter yang dapat dimuat ke dalam modul elektrokimia yaitu bersyukur, jujur, disiplin, kerja sama, rasa ingin tahu, peduli lingkungan, kerja keras dan mandiri. elaui muatan nilai-nilai karakter tersebut diharapkan peserta didik dapat menerapkannya dalam proses proses pembelajaran maupun kehidupan sehari-hari. Penyisipan karakter disampaikan secara langsung maupun tidak langsung. Penyispan langsung berupa ajakan bermuatan berkarakter baik yang dimuat dalam permata ilmu dan petunjuk pengerjaan tugas. Penyisipan nilai karakter tidak langsung dapat berupa percakapan yang dimuat dalam materi pembelajaran. Salah satu bahan ajar yang dapat digunakan adalah modul.

Modul merupakan sumber belajar yang ideal bagi peserta didik karena dapat digunakan sebagai sumber belajar mandiri (Akbar, 2013). 
Selain itu di dalam modul terdapat komponenkomponen yang dapat membantu peserta didik untuk memahami materi pelajaran secara komprehensif. Komponen-komponen yang dimaksud yaitu materi, lembar kerja (baik praktikum maupun non praktikum), dan lembar kegiatan peserta didik (Sudjana, 2007).

Berdasarkan masalah di atas, peneliti bermaksud untuk mengembangkan modul kimia bermuatan karakter untuk peserta didik program keahlian Teknik Instalasi Tenaga Listrik. Pengembangan modul kimia bermuatan karakter diharapkan dapat membantu peserta didik memiliki karakter-karakter unggul seperti jujur, displin, kreatif, mandiri dll. Selain itu dengan adanya modul tersebut peserta didik diharapkan mampu mengetahui relevansi antara ilmu kimia dengan program keahlian yang mereka ambil. Tujuan dari penelitian ini adalah untuk mengetahui karakteristik dan kelayakan modul bermuatan pendidikan karakter pada materi elektrokimia program keahlian Teknik Instalasi Tenaga Listrik yang dikembangkan.

\section{Metode Penelitian}

Penelitian ini adalah penelitian pengembangan (Research and Development) yang mengambangkan bahan ajar berupa modul elektrokimia bermuatan pendidikan karakter untuk program keahlian Teknik Instalasi Tenaga Listrik. Penelitian ini mengadaptasi model pengembangan dari Thiagarajan (1974) yang dikenal dengan 4- $D$ yaitu define (pendefinisian), design (perancangan), develop (pengembangan), dan disseminate (penyebaran). Namun pada penelitian ini dilakukan sampai pada tahap ke tiga saja yakni develop (pengembangan) pada bagian initial testing (uji coba terbatas) karena keterbatasan waktu dan biaya.

Subjek penilitian ini adalah peserta didik kelas X program keahlian Teknik Instalasi
Tenaga Listrik (TITL) SMK Negeri 5 Semarang. Uji coba produk dilakukan pada skala kecil dengan mengambil sembilan peserta didik, yaitu 3 peserta didik dengan tingkat pemahaman tinggi, 3 peserta didik dengan tingkar pemahaman sedang dan 3 peserta didik dengan tingkat pemahaman rendah.

Teknik pengumpulan data dalam penelitian ini adalah observasi, wawancara, dokumentasi, angket dan tes. Observasi dan wawancara digunakan untuk mendapatkan data sebagai studi pendahuluan. Sebelum diuji cobakan modul yang dikembangkan divalidasi oleh para ahli materi dan ahli media dengan menggunakan instrumen lembar validasi modul yang telah disesuaikan dengan indikator dari BSNP (2014). Instrumen validitas modul ditentukan dengan angket validasi menggunakan rating scale 5 . Kemudian hasil validasi dihitung dengan validitas Aiken's V yang terdapat pada Azwar (2012) dengan rumus sebagai berikut:

$$
\begin{aligned}
& \mathrm{V}=\frac{\sum s}{[n(\sigma-1)]} \\
& \mathrm{s} \quad=\mathrm{r}-\mathrm{l}_{0} \\
& \text { Keterangan : } \\
& \mathrm{V} \quad \text { = indeks kesepakatan penilai mengenai validitas } \\
& \text { butir } \\
& \mathrm{s} \quad=\text { skor terendah yang ditetapkan setiap penilai }
\end{aligned}
$$

Setelah itu nilai $\mathrm{V}$ yang telah didapatkan dikonversikan dalam bentuk tabel kriteria yang disajikan pada Tabel 1.

Tabel 1. Kriteria Kevalidan Aiken's

\begin{tabular}{lcc}
\hline No & Indeks & Kevalidan \\
\hline 1. & $>0,8$ & Sangat valid \\
2. & $0,41-0,8$ & Cukup valid \\
3. & $\leq 0,40$ & Kurang valid \\
\hline & & (Retnawati, 2016)
\end{tabular}

72

Copyright (C) 2019 JEC | ISSN 2715-3029 (p) 2685-4880 (e)

Volume 1, Nomor 2, 2019 


\section{Hasil Penelitian dan Pembahasan}

Modul pembelajaran yang telah dibuat dan dikembangkan menggunakan prosedur dari model pengembangan $4 D$ (Thiagarajan, 1974) yang telah dimodifikasi menjadi $3 D$ dengan tahap sebagai berikut: tahap define, design dan develop. Adapun tahap model pengembngan $3 D$ yang dilakukan yaitu

\section{Tahap Define}

Tahap define disebut juga tahap analisis kebutuhan. Tahap define dilakukan untuk menetapkan dan mendefinisikan syarat-syarat pengembangan.

a. Analisis Ujung Depan (Front-End Analysis)

Tahap ini bertujuan untuk mengetahui masalah dasar yang terdapat di SMK N 5 Semarang. Kegiatan yang dilakukan pada tahap ini yaitu observasi, wawancara guru kimia SMK dan penyebaran angket kebutuhan peserta didik. Adapun masalah dasar dalam pembelajaran kimia di SMK N 5 Semarang yaitu;

1) Bahan ajar yang digunakan guru dalam pembelajaran kimia adalah buku paket dari pemerintah yang tidak terintegrasi dengan program keahlian peserta didik.

2) Terbatasnya jumlah bahan ajar yang digunakan, sehingga peserta didik harus meminjam ke perpustakaan ketika pelaksanaan pembelajaran kimia dan mengembalikannya kembali setelah pembelajaran kimia selesai.

3) Sumber belajar yang digunakan tidak relevan dengan program keahlian yang diambil peserta didik.

4) Banyaknya kasus degradasi moral di kalangan pelajar, seperti masih ditemukannya peserta didik yang tawuran dengan peserta didik sekolah lain.

5) Masih banyak peserta didik yang tidak mengutamakan kejujuran, seperti kebiasaan mencontek dalam ujian.

6) Peserta didik kurang antusias terhadap pembelajaran kimia.

7) Peserta didik menganggap bahwa pembelajaran kimia tidak ada kaitannya dengan program keahlian yang mereka ambil.

8) Ketercapaian ketuntasan hasil ulangan kimia peserta didik masih rendah.

\section{b. Analisis Peserta Didik}

Tahap ini bertujuan untuk mengetahui karakteristik peserta didik. Data analisa ini diambil dari angket gaya belajar peserta didik dan angket kebutuhan peserta didik. Hasil angket peserta didik ditampilkan dalam Tabel 2.

Tahap 2. Hasil Angket Gaya Belajar Peserta Didik

\begin{tabular}{lc}
\hline \multicolumn{1}{c}{ Gaya Belajar } & Persentase \\
\hline Audio & $12 \%$ \\
Visual & $24 \%$ \\
Kinestetik & $6 \%$ \\
Audio Kinestetik & $15 \%$ \\
Audio Visual & $21 \%$ \\
Visual Kinestetik & $18 \%$ \\
Audio Visual Kinestetik & $9 \%$ \\
\hline
\end{tabular}

Berdasarkan Tabel 2 gaya belajar peserta didik cenderung seimbang dengan yang dominan adalah gaya belajar visual. Peneliti berinisiatif mengembangkan bahan ajar berbentuk visual dengan dilengkapi praktikum dalam pembelajaran dan terdapat link video pembelajaranpada bahan ajar yang dikembangkan, sehingga semua peserta didik dapat memahami materi tanpa mengecualikan gaya belajarnya.

Tahap 3. Hasil Angket Kebutuhan Peserta Didik

\begin{tabular}{lc}
\hline $\begin{array}{l}\text { Pelajaran apa yang anda } \\
\text { sukai }\end{array}$ & Persentase \\
\hline a. Kimia & $14 \%$ \\
b. Selain kimia & $86 \%$ \\
\hline
\end{tabular}

Berdasarkan Tabel $\mathbf{3}$ hasil angket kebutuhan peserta didik diketahui bahwa sebanyak $86 \%$ peserta didik tidak menyukai pelajaran kimia. 
Tabel 4. Hasil Angket Kebutuhan Peserta Didik

\begin{tabular}{ll}
\hline $\begin{array}{l}\text { Materi yang dianggap sulit } \\
\text { dalam pelajaran kimia }\end{array}$ & Persentase \\
\hline a. SPU dan Struktur Atom & $12 \%$ \\
b. Redoks & $22 \%$ \\
c. Elektrokimia & $37 \%$ \\
d. Asam Basa & $17 \%$ \\
e. Lainnya & $12 \%$ \\
\hline
\end{tabular}

Berdasarkan Tabel 4. sebanyak 37\% peserta didik mengalami kesulitan dalam materi elektrokimia.

Tabel 5. Hasil Angket Kebutuhan Peserta Didik

\begin{aligned} & \hline $\begin{array}{l}\text { Apa buku pegangan yang } \\ \text { dibuat referensi untuk } \\ \text { pembelajaran kimia }\end{array}$ Persentase \\ & \hline a. Buku paket \\ & b. LKS $18 \% \\ &$ c. Modul $2 \% \\ &$ d. Tidak ada buku $2 \% \\ &$\hline\end{aligned}

Berdasarkan Tabel 5. sebanyak 78\% peserta didik menyatakan bahwa dalam pembelajaran kimia tidak ada buku yang dijadikan referensi dalam pembelajaran. Peneliti juga menggali informasi tentang kriteria bahan ajar yang menarik menurut peserta didik.

Tabel 6. Hasil Angket Kebutuhan Peserta Didik

\begin{tabular}{rlc}
\hline $\begin{array}{l}\text { Bagaimana kriteria bahan } \\
\text { ajar yang menarik untuk } \\
\text { dipelajari }\end{array}$ & Persentase \\
\hline \multicolumn{3}{c}{ a. Memuat gambar } \\
b. Dihubungkan dengan \\
program keahlian \\
$\begin{array}{l}\text { yang diambil } \\
\text { c. } \begin{array}{l}\text { Dikaitkan dengan } \\
\text { kehidupan sehari-hari }\end{array}\end{array}$ \\
\hline
\end{tabular}

Berdasarkan Tabel 6 sebanyak 52\% peserta didik menyatakan bahwa kriteria bahan ajar yang menarik adalah bahan ajar

74

Copyright (C) 2019 JEC | ISSN 2715-3029 (p) 2685-4880 (e)

Volume 1, Nomor 2, 2019 tersebut dikaitkan dengan kehidupan seharihari dan 35\% peserta didik menyatakan bahwa kriteria bahan ajar yang menarik adalah bahan ajar tersebut dikaitkan dengan kehidupan sehari-hari.

Tabel 4.7 Hasil Angket Peserta Didik

\begin{tabular}{lc}
\hline $\begin{array}{l}\text { Apakah anda masih melihat } \\
\text { teman-teman anda } \\
\text { melakukan tawuran dengan } \\
\text { sekolah lain? }\end{array}$ & Persentase \\
\hline Ya & $57 \%$ \\
Tidak & $43 \%$ \\
\hline
\end{tabular}

Berdasarkan Tabel $\mathbf{7}$ menunjukkan bahwa $57 \%$ peserta didik masih melihat teman-teman mereka tawuran dengan sekolah lain. Selain itu, peneliti juga menggali informasi tentang antusiasme peserta didik dalam bekerja sama dengan teman.

Tabel 8. Hasil Angket Peserta Didik

\begin{tabular}{lc}
$\begin{array}{l}\text { Apakah anda lebih suka } \\
\text { nonton TV daripada belajar } \\
\text { kelompok } \\
\text { mentukelesaikan tugas? }\end{array}$ & Persentase \\
Ya & $62 \%$ \\
Tidak & $38 \%$ \\
\hline
\end{tabular}

Berdasarkan Tabel 8 menunjukkan bahwa $62 \%$ peserta didik tidak antusias dalam belajar kelompok, peserta didik lebih senang menonton TV. Hal tersebut menunjukkan bahwa antusiasme peserta didik dalam belajar dan bekerja sama rendah.

Tabel 9. Hasil Angket Peserta Didik

\begin{tabular}{lc}
\hline $\begin{array}{l}\text { Apakah saat ujian anda } \\
\text { bekerja sama / mencontek } \\
\text { dengan teman? }\end{array}$ & Persentase \\
\hline Ya & $45 \%$ \\
Tidak & $55 \%$ \\
\hline
\end{tabular}


Berdasarkan Tabel 9. menunjukkan bahwa $45 \%$ peserta didik mengaku melakukan kerja sama saat ujian. Dari hasil analisis angket tersebut peneliti mengembangkan modul bermuatan pendidikan karakter yang dikaitkan dengan program keahlian Teknik Instalasi Tenaga Listrik pada materi Elektrokimia.

Tabel 10. Hasil Angket Kebutuhan Peserta Didik

\begin{tabular}{lcc}
\hline $\begin{array}{l}\text { Bagaimana kriteria bahan } \\
\text { ajar yang menarik } \\
\text { dipelajari }\end{array}$ & $\begin{array}{c}\text { Persentase } \\
\text { untuk }\end{array}$ & \\
\hline $\begin{array}{l}\text { a. Memuat gambar } \\
\text { b. Dihubungkan dengan } \\
\text { program keahlian yang }\end{array}$ & $35 \%$ \\
$\begin{array}{l}\text { diambil } \\
\text { c. Dikaitkan dengan } \\
\text { kehidupan sehari-hari }\end{array}$ & $52 \%$ \\
\hline
\end{tabular}

Berdasarkan Tabel 10. sebanyak 52\% peserta didik menyatakan bahwa kriteria bahan ajar yang menarik adalah bahan ajar tersebut dikaitkan dengan kehidupan seharihari dan $35 \%$ peserta didik menyatakan bahwa kriteria bahan ajar yang menarik adalah bahan ajar tersebut dikaitkan dengan kehidupan sehari-hari.

c. Analisis Tugas (Task Analysis)

Analisis tugas dilaksanakan dengan menganalisis secara menyeluruh terhadap tugas yang dituntut dalam mata pelajaran kimia. Pada tahap ini diperoleh data bahwa masih banyak peserta didik yang mengalami kesulitan dalam menyelesaikan tugas-tugas yang diberikan guru. Hal ini dapat diketahui dari nilai ulangan peserta didik yang sebagian besar tidak tuntas / di bawah KKM.

d. Analisis Konsep (Concept Analysis)

Analisis konsep bertujuan untuk mengidentifikasi konsep pokok yang digunakan sebagai dasar dalam penyusunan materi pada modul yang dikembangkan. Langkah awal yang dilakukan adalah analisis terhadap KI dan KD kurikulum 2013 kimia SMK yang bersumber dari silabus yang digunakan di SMK N 5 Semarang untuk mentukan cakupan dan batasan materi serta indikator pembelajaran.

e. Analisis Tujuan Pembelajaran (Specifying Instructional Objectuves)

Perumusan tujuan pembelajaran dilakukan untuk menentukan indikator pencapaian pembelajaran yang didasarkan atas analisis tugas dan konsep yang telah dilakukan sebelumnya.

\section{Tahap Design}

Hasil analisis pada tahap define digunakan sebagai acuan untuk mendesain modul elektrokimia bermuatan pendidikan karakter program keahlian Teknik Instalasi Tenaga Listrik.

\section{Develop}

\section{a. Penilaian Ahli (Expert Appraisal)}

Expert appraisal dilakukan untuk mengetahui kelayakan modul yang dikembangkan. Rancangan prototipe awal (prototipe I) yang telah disusun pada tahap design dilakukan penilaian atau validasi oleh para ahli/validator yang berkompeten di bidangnya. Validasi dilakukan melalui dua tahap yaitu validasi ahli media dan validasi di bidang materi kimia. Dalam validasi materi dan media ini terdapat 3 validator.

Penilaian kelayakan produk dilakukan oleh validator ahli materi dan ahli media menggunakan instrumen penilaian yaitu lembar validasi yang berisi beberapa aspek dan indikator yang telah ditentukan. Saran dari validator di bidang materi kimia dan media digunakan sebagai dasar untuk memperbaiki produk menjadi lebih baik. Hasil validasi ahli di bidang materi kimia dan validator ahli media dapat dilihat pada tabel berikut. 
Tabel 11 Hasil Penilaian Validasi Ahli Materi Tahap Pertama

\begin{tabular}{|c|c|c|c|c|}
\hline \multirow[b]{2}{*}{ No. } & \multirow{2}{*}{ Aspek Penilaian } & \multicolumn{3}{|c|}{ Validator } \\
\hline & & I & II & III \\
\hline \multicolumn{5}{|c|}{ KELAYAKAN ISI } \\
\hline \multirow{2}{*}{$\begin{array}{l}1 . \\
2 .\end{array}$} & Kesesuaian dengan KI \& KD & 4 & 5 & 5 \\
\hline & $\begin{array}{l}\text { Kesesuaian dengan kebutuhan } \\
\text { peserta didik }\end{array}$ & 3 & 4 & 4 \\
\hline & Keakuratan materi & 3 & 4 & 4 \\
\hline & $\begin{array}{l}\text { Keterkinian/kekontekstualan } \\
\text { fitur (contoh) }\end{array}$ & 3 & 4 & 3 \\
\hline \multicolumn{5}{|c|}{ KEBAHASAAN } \\
\hline 5. & Kejelasan informasi & 3 & 5 & 3 \\
\hline & Aspek kelayakan penyajian & 3 & 4 & 4 \\
\hline \multicolumn{5}{|c|}{ TEKNIK PENYAJIAN } \\
\hline 7. & Pendukung penyajian & 3 & 5 & 4 \\
\hline & Penyajian pembelajaran & 4 & 4 & 4 \\
\hline \multicolumn{5}{|c|}{$\begin{array}{l}\text { ORIENTASI MUATAN PENDIDIKAN KARAKTER } \\
\text { \& KONTEKS KEJURUAN }\end{array}$} \\
\hline & $\begin{array}{l}\text { Implementasi nilai karakter } \\
\text { melalui materi elektrokimia }\end{array}$ & 3 & 4 & 4 \\
\hline 10. & $\begin{array}{l}\text { Prinsip elektrokimia } \\
\text { terintegrasi konteks kejuruan }\end{array}$ & 4 & 4 & 4 \\
\hline
\end{tabular}

Sedangkan hasil validasi ahli media tahap 1 dapat dilihat pada Tabel 12 sebagai berikut:

Tabel 12 Hasil Penilaian Validasi Ahli Media Tahap Pertama

\begin{tabular}{crccc}
\hline \multirow{2}{*}{ No. } & \multirow{2}{*}{ Aspek Penilaian } & \multicolumn{3}{c}{ Validator } \\
\cline { 3 - 5 } & & I & II & III \\
\hline 1. & Penyajian modul & 3 & 5 & 5 \\
2. & Kelayakan kegrafikan & 3 & 4 & 4 \\
3. & Kualitas tampilan & 4 & 4 & 4 \\
\hline
\end{tabular}

Berdasarkan hasil validasi oleh ahli materi dan ahli media tahap pertama, sesuai dengan hasil rumus Aiken's V didapatkan hasil bahwa modul elektrokimia bermuatan pendidikan karakter program keahlian Teknik Instalasi Tenaga Listrik memiliki nilai koefisien (V) Aiken's V sebesar 0,71. Kemudian hasil nilai Aiken's V tersebut dikonversikan ke dalam tabel kevalidan menurut Retnawati (2016).
Tabel 13 Kriteria Kevalidan

\begin{tabular}{lcc}
\hline No & Indeks & Kevalidan \\
\hline 1. & $>0,8$ & Sangat layak \\
2. & $0,41-0,8$ & Cukup layak \\
3. & $\leq 0,40$ & Kurang layak \\
\hline
\end{tabular}

Berdasarkan Tabel 13 modul elektrokimia bermuatan pendidikan karakter program keahlian Teknik Instalasi Tenaga Listrik dalam kategori cukup valid. Setelah dilakukan penilaian kemudian modul yang dikembangkan direvisi sesuai dengan saran dari validator. Setelah dilakukan revisi kemudian validator memberikan nilai kembali pada lembar penilaian validasi tahap 2. Berikut adalah hasil nilai validasi tahap 2 oleh ahli materi dan media.

Tabel 14 Hasil Penilaian Validasi Ahli Materi Tahap 2

\begin{tabular}{|c|c|c|c|c|}
\hline \multirow[b]{2}{*}{ No. } & \multirow[b]{2}{*}{ Aspek Penilaian } & \multicolumn{3}{|c|}{ Validator } \\
\hline & & I & II & III \\
\hline \multicolumn{5}{|c|}{ KELAYAKAN ISI } \\
\hline 1. & Kesesuaian dengan KI \& KD & 4 & 5 & 5 \\
\hline 2. & Kesesuaian dengan & 4 & 4 & 4 \\
\hline \multirow{2}{*}{$\begin{array}{l}3 . \\
4 .\end{array}$} & Keakuratan materi & 4 & 4 & 4 \\
\hline & $\begin{array}{l}\text { Keterkinian/kekontekstualan } \\
\text { fitur (contoh) }\end{array}$ & 5 & 4 & 3 \\
\hline \multicolumn{5}{|c|}{ KEBAHASAAN } \\
\hline 5. & Kejelasan informasi & 4 & 5 & 3 \\
\hline 6. & Aspek kelayakan penyajian & 4 & 4 & 4 \\
\hline \multicolumn{5}{|c|}{ TEKNIK PENYAJIAN } \\
\hline 7. & Pendukung penyajian & 5 & 5 & 4 \\
\hline 8. & Penyajian pembelajaran & 4 & 4 & 4 \\
\hline \multicolumn{5}{|c|}{ ORIENTASI MUATAN PENDIDIKAN } \\
\hline \multicolumn{5}{|c|}{ KARAKTER \& KONTEKS KEJURUAN } \\
\hline 9. & $\begin{array}{l}\text { Implementasi nilai karakter } \\
\text { melalui materi elektrokimia }\end{array}$ & 5 & 4 & 4 \\
\hline \multirow[t]{2}{*}{10.} & elektrokimia & & & \\
\hline & $\begin{array}{l}\text { terintegrasi } \\
\text { kejuruan }\end{array}$ & 5 & 4 & 4 \\
\hline
\end{tabular}


Tabel 15 Hasil validasi ahli media

\begin{tabular}{clrcc}
\hline \multirow{2}{*}{ No. } & \multirow{2}{*}{ Aspek Penilaian } & \multicolumn{3}{c}{ Validator } \\
\cline { 3 - 5 } & & I & II & III \\
\hline 1. & Penyajian modul & 4 & 5 & 5 \\
2. & Kelayakan kegrafikan & 4 & 4 & 4 \\
3. & Kualitas tampilan & 5 & 4 & 4 \\
\hline
\end{tabular}

Berdasarkan hasil validasi tahap 2 oleh ahli materi dan ahli media, sesuai dengan rumus Aiken's V bahwa modul elektrokimia bermuatan pendidikan karakter program keahlian Teknik Instalasi Tenaga Listrik memiliki nilai koefisien (V) Aiken's V sebesar 0,80. Hasil nilai Aiken's V kemudian dikonversikan ke dalam tabel kevalidan menurut Retnawati (2016) pada Tabel 11. Berdasarkan Tabel 11 modul elektrokimia bermuatan pendidikan karakter program keahlian Teknik Instalasi Tenaga Listrik dikategorikan sangat layak.

\section{b. Tes Pengembangan (Developmental Testing) \\ Developmental testing merupakan} kegiatan uji coba rancangan dari produk yang dikembangkan pada sasaran sesungguhnya. Tahap developmental testing ini hanya sampai pada initial testing yaitu rancangan produk diujikan di lapangan dengan jumlah pengguna terbatas. Uji coba rancangan ini bertujuan untuk mengetahui tanggapan peserta didik terhadap kualitas modul yang dikembangkan. Adapun hasil penilaian tanggapan peserta didik terhadap produk yang dikembangkan dapat dilihat pada Tabel 16.

Tabel 16 Hasil Angket Tanggapan Peserta Didik

\begin{tabular}{|c|c|c|c|c|}
\hline No. & Responden & Skor & $\%$ & Kategori \\
\hline 1. & $\mathrm{R}-1$ & 100 & $80 \%$ & $\begin{array}{l}\text { Cukup } \\
\text { Valid }\end{array}$ \\
\hline 2. & $\mathrm{R}-2$ & 104 & $83 \%$ & $\begin{array}{c}\text { Cukup } \\
\text { Valid }\end{array}$ \\
\hline 3. & $\mathrm{R}-3$ & 107 & $85 \%$ & $\begin{array}{c}\text { Sangat } \\
\text { Valid }\end{array}$ \\
\hline 4. & $\mathrm{R}-4$ & 108 & $86 \%$ & $\begin{array}{c}\text { Sangat } \\
\text { Valid }\end{array}$ \\
\hline 5. & $\mathrm{R}-5$ & 109 & $87 \%$ & $\begin{array}{c}\text { Sangat } \\
\text { Valid }\end{array}$ \\
\hline 6. & $\mathrm{R}-6$ & 115 & $92 \%$ & Sangat \\
\hline
\end{tabular}

\begin{tabular}{|c|c|c|c|c|}
\hline 7. & $\mathrm{R}-7$ & 110 & $88 \%$ & $\begin{array}{c}\text { Valid } \\
\text { Sangat }\end{array}$ \\
\hline 8. & R-8 & 109 & $87 \%$ & $\begin{array}{l}\text { Sangat } \\
\text { Valid }\end{array}$ \\
\hline 9. & R-9 & 101 & $80 \%$ & $\begin{array}{l}\text { Cukup } \\
\text { Valid } \\
\end{array}$ \\
\hline & Jumlah & 963 & $\begin{array}{c}85,3 \\
\% \\
\end{array}$ & $\begin{array}{l}\text { Sangat } \\
\text { Valid }\end{array}$ \\
\hline
\end{tabular}

Keterangan:

$\mathrm{R}=$ Responden

Berdasarkan hasil tanggapan 9 responden pada uji coba kelas kecil, 6 orang peserta didik menyatakan bahwa modul yang dikembangkan "sangat valid" dan 3 responden menyatakan "cukup valid". Dari keseluruhan responden berdasarkan hasil data di atas, sebanyak 85,3\% rata-rata responden menyatakan bahwa modul yang dikembangkan sangat valid.

Setelah mengisi angket, peserta didik diminta untuk mengisi tanggapan tentang modul yang digunakan. Tanggapan tersebut berupa kritik dan saran dalam bentuk angket terbuka. Berdasarkan hasil angket didapatkan tanggapan bahwa modul yang dikembangkan mudah dipahami karena dikaitkan dengan kehidupan sehari-hari dan program keahlian peserta didik.

\section{B. Analisis Data}

Pengembangan modul elektrokimia bermuatan pendidikan karakter program keahlian Teknik Instalasi Tenaga Listrik diawali dengan penelitian pendahuluan untuk mengetahui permasalahan yang ada di SMK N 5 Semarang. Berdasarkan hasil analisis angket kebutuhan peserta didik, wawancara kepada guru kelas dan observasi lapangan diperoleh informasi bahwa dalam pembelajaran kimia di sekolah peserta didik mengalami kesulitan dalam belajar karena terbatasnya bahan ajar yang tersedia. Bahan ajar yang ada di SMK N 5 Semarang cenderung sama dengan bahan ajar yang ada di SMA, sehingga peserta didik tidak mengetahui manfaat ilmu kimia dalam program keahlian yang mereka ambil. Hal itu sesuai dengan penelitian Hartanto \& Fordiana (2018) 
yang menyatakan bahwa pembelajaran kimia merupakan mata pelajaran dasar kejuruan yang berguna untuk mendukung mata pelajaran program keahlian, sehingga peserta didik mampu menggunakan pengetahuan dasar kimia dalam kehidupan sehari-hari dan sebagai landasan untuk mengembangkan kompetensi di masing-masing bidang keahlian.

Selain itu berdasarkan hasil analisis angket siswa ditemukan juga permasalahan degradasi moral peserta didik, seperti masih adanya kasus tawuran yang dilakukan peserta didik SMK N 5 Semarang. Hal tersebut sesuai dengan penelitian Samson \& Allida (2018) yang menyatakan bahwa degradasi moral pada sebagian remaja merupakan tantangan bagi dunia pendidikan. Hasil penelitian pendahuluan ini menjadi landasan yang kuat perlunya pengembangan suatu bahan ajar yang mengaitkan dengan kehidupan sehari-hari dan program keahlian peserta didik dan dapat membimbing peserta didik untuk memiliki karakter positif serta turut melibatkan peserta didik secara mandiri dalam proses pembelajaran.

Penelitian dan pengembangan ini menghasilkan sebuah produk berupa modul elektrokimia bermuatan pendidikan karakter program keahlian Teknik Instalasi Tenaga Listrik (TITL). Modul yang telah dikembangakan kemudian divalidasi oleh ahli materi dan ahli media berdasarkan kriteria kelayakan isi, bahasa, penyajian, orientasi muatan pendidikan karakter dan integrasi konteks kejuruan, kegrafisan dan kualitas tampilan.

Setiap aspek memiliki beberapa macam komponen dan setiap komponen terdiri atas beberapa rubrik penilaian. Berdasarkan penilaian para ahli pada tahap pertama didaptkan skor Aiken's V sebesar 0,72 dengan kategori cukup layak. Penilaian ahli pada tahap kedua mengalami peningkatan menjadi 0,8 dengan kategori sangat layak. Peningkatan skor Aiken's V tampak pada Gambar 1.

\section{8}

Copyright (C) 2019 JEC | ISSN 2715-3029 (p) 2685-4880 (e)

Volume 1, Nomor 2, 2019

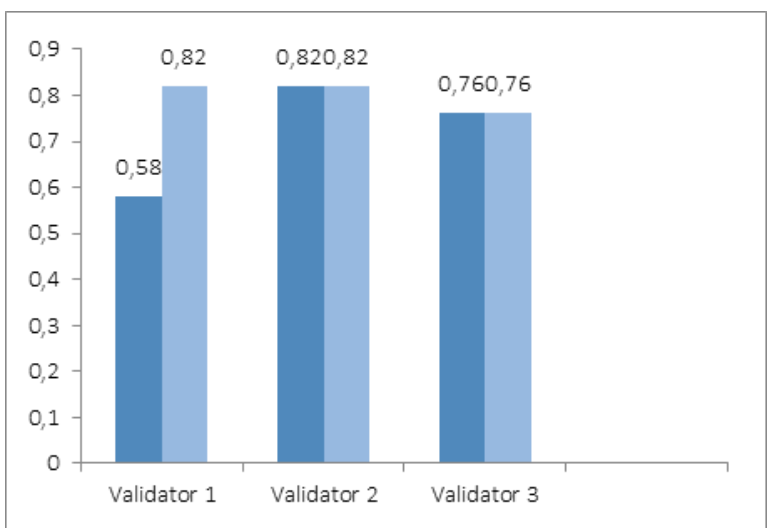

Gambar 1. Peningkatan Hasil Penilaian Ahli

Setelah dilakukan validasi dari ahli materi dan ahli media, kemudian modul yang dikembangkan diujikan kepada 9 peserta didik yang terdiri dari 3 peserta didik dengan tingkat pemahaman tinggi, 3 peserta didik dengan tingkar pemahaman sedang dan 3 peserta didik dengan tingkat pemahaman rendah. Hasil angket tanggapan peserta didik tampak pada

\section{Gambar 2.}

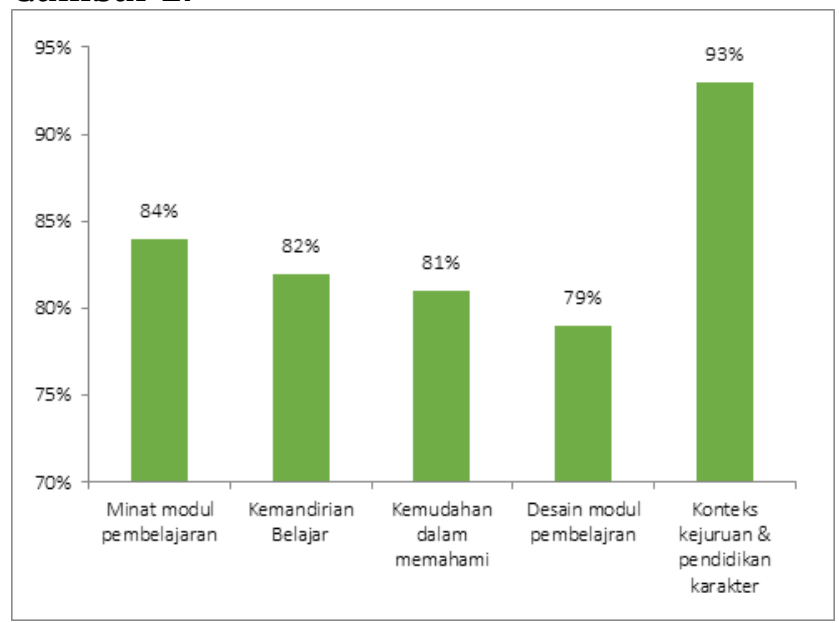

Gambar 2. Hasil Angket Tanggapan Peserta Didik

Berdasarkan Gambar 2 di dapatkan informasi bahwa aspek penilaian terendah pada modul yang dikembangkan terdapat pada aspek desain modul pembelajaran dengan persentase 
79\%. Hal ini disebabkan karena desain modul yang dikembangkan cukup sederhana. Aspek dengan persentase tertinggi ada pada konteks kejuruan dan pendidikan karakter dengan persentase 93\%. Hal ini dikarenakan peserta didik antusias terhadap pembelajaran kimia yang dikaitkan dengan program keahlian mereka. Sejalan dengan penelitian Chiang \& Lee (2016) menyatakan bahwa materi kimia yang terintegrasi dengan program keahlian peserta didik akan meningkatkan motivasi belajar peserta didik. Selain itu peserta didik juga antusias terhadap nilai-nilai pendidikan karakter yang ada di dalam modul. Rata-rata dari semua aspek termasuk dalam kategori sangat valid.

Proses selanjutnya yaitu uji keterbacaan modul yang bertujuan untuk mengetahui apakah modul terbaca dengan baik atau tidak. Berikut hasil analisis uji keterbacaan modul;

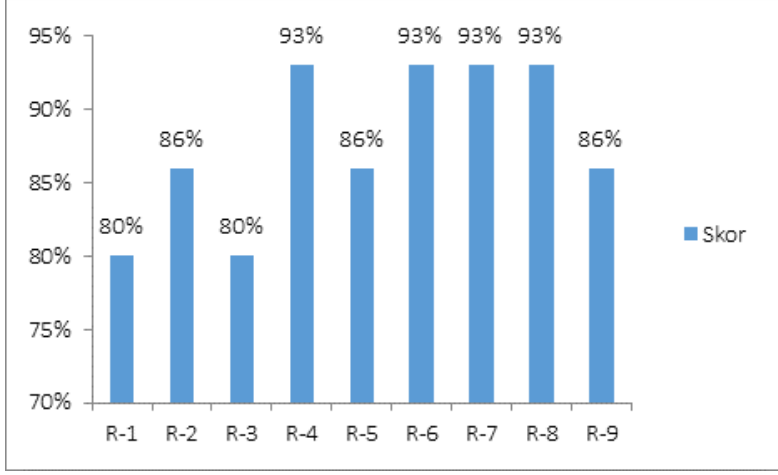

Gambar 3. Analisis Hasil Tes Keterbacaan Modul

Berdasarkan Gambar 3 diperoleh hasil rata-rata uji keterbacaan modul sebesar $87,7 \%$ dengan kategori tinggi dan tidak perlu revisi. Menurut Javed \& Eng, (2015) modul yang memiliki tingkat keterbacaan tinggi memiliki arti mudah dipahami oleh peserta didik karena suatu pemahanan dapat diperoleh dengan membaca.

Data hasil rata-rata pretest dan posttest serta skor N-gain ditunjukkan pada Tabel 17.
Tabel 17. Rerata hasil pretest, posttest dan Ngain

\begin{tabular}{ccc}
\hline Rerata Pretest & Rerata Posttest & N-gain Score \\
\hline 30 & 64,4 & 0,49 \\
\hline
\end{tabular}

Berdasarkan kriteria Hake \& Meltzer (2002) kenaikan hasil belajar peserta didik termasuk kategori sedang hal ini menunjukkan bahwa modul yang dikembangkan cukup dapat meningkatkan hasil belajar peserta didik. Hal ini sesuai dengan penelitian Lee dan Osman (2012) yang menunjukkan bahwa modul dapat meningkatkan hasil belajr peserta didik.

\section{Simpulan dan Saran}

Simpulan

Berdasarkan hasil pengembangan dan uji lapangan maka dapat disimpulkan bahwa kualitas modul kimia bermuatan pendidikan karakter pada materi program keahlian Teknik Instalasi Tenaga Listrik berdasarkan penilaian validator ahli materi dan ahli media dinyatakan "sangat layak" dengan skor Aiken's V sebesar 0,8 . Hal ini diperkuat dengan hasil angket tanggapan peserta didik terhadap kualitas modul dengan persentase sebesar 85,3\% sehingga modul yang dikembangkan dalam kateori "sangat valid". Hasil uji keterbacaan modul dengan rata-rata $87,7 \%$ dalam kategori "tinggi". Karakteritik modul yang dikembangkan yaitu disusun berdasarkan keterkaitan materi kimia dengan program keahlian Teknik Instalasi Tenaga Listrik serta muatan pendidikan karrakter di dalamnya. Hal ini terlihat pada konten materi kimia yang dihubungkan dengan kelistrikan seperti pada sistem grounding dengan tujuan untuk meningkatkan relevansi dengan materi kejuruan. Muatan pendidikan karakter di dalam modul terlihat pada konten nilai karakter pengembangan diri, permata ilmu dan latihan soal yang diberikan pada modul diintegrasikan dengan program keahlian Teknik Instalasi Tenaga Listrik dan pendidikan karakter. 
Saran

Muatan pendidikan karakter pada modul yang dikembangkan perlu dikaji ulang dalam hal korelasi antara ketepatan secara teoritis (literatur) apakah nilai-nilai karakter itu bisa diintegrasikan dengan suatu modul pembelajaran. Jika memang terdapat referensi yang mengatakan demikian maka perlu dikaji ulang bagaimana teknis mengintegrasikannya.

Materi elektrokimia untuk peserta didik SMK perlu dikaji ulang untuk peserta didik SMK program keahlian Teknik Instalasi Tenaga Listrik

Nilai-nilai karakter yang harus dibenahi di SMK N 5 Semarang tidak bersesuaian dengan solusi yang diterdapat dalam modul. Oleh karena itu, jika nilai karakter ingin diintegrasikan dalam suatu modul maka solusinya karakter yang harus diperbaiki ada dalam modul. Itupun dalam hal mengintegrasikan nilai karakter dalam suatu modul pembelajaran maka landasan teoritisnya harus kuat.

\section{Daftar Pustaka}

Akbar, S. 2013. Instrumen Perangkat Pembelajaran. Bandung: PT Remaja Rosdakarya.

Azwar, S. 2012. Reliabiltas dan Validitas. Edisi 4. Yogyakarta : Pustaka Pelajar

Chiang, C. L., \& Lee, H. 2016. The Effect of Project-Based Learning on Learning Motivation and Problem-Solving Ability of Vocational High School Students. International Journal of Information and Education Technology, 6(9), 709-712.

Hartanto, S., \& Fordiana, R. 2018. Learning Need Analysis of Vocational High School's Chemical Subject in Mechanical Engineering Departement. International
Journal of Engineering and Technology, $7(3.25), 656-658$.

Haryati, S. 2013. Pendidikan Karakter dalam Kurikulum 2013. FKIP-UTM.

Javed, M., \& Eng, L. S. 2015. Developing Reading Comprehension Modules to Facilitate Reading Comprehension among Malaysian Secondary School ESL Students. International Journal of Instruction, 8(2), 139-154.

Lee, T. T., \& Osman, K. 2012. Interactive Multimedia Module with Pedagogical Agents : Formative Evaluation. International Education Studies, 5(6), 5064.

Majid, A. \& Andayani, D.. 2011. Pendidikan Karakter Perspektif Islam. Bandung: Remaja Rosdakarya.

Hake \& Meltzer, D. E. 2002. The Relationship Between Mathematics Preparation and Conceptual Learning Gains in Physics: A Possible "Hidden Variable" in Diagnostic Pretest Scores. American Association of Physics Teachers, 1259-1268.

Retnawati, H. 2016. Analisis Kuantitatif Instrumen Penelitian. Yogyakarta: Parama Publishing

Samson, B., \& Allida, V. 2018. Moral Decline in Schools: Reflections on Public Secondary Schools in Iganda District, Uganda. Baraton Interdisciplinary Research Journal, 8(Special Issue), 1-9.

Sudjana, Nana dan Ahmad Rivai. 2007. Teknologi Pengajaran. Bandung: Sinar Baru Algesindom

80

Copyright (C) 2019 JEC | ISSN 2715-3029 (p) 2685-4880 (e)

Volume 1, Nomor 2, 2019 
Thiagarajan. 1974. Instrucctional Development for Training Teachers of Exceptional Children A sourcebook, Indiana University, Bloomington: Indiana.

Zamtinah, Kurniawan, U., Sarosa, D., \& Tyasari, R. (2011). Model Pendidikan Karakter Untuk Sekolah Menengah Kejuruan. FT Universitas Negeri Yogyakarta. 